\title{
Studi Pemikiran Mestika Zed Tentang Pemerintah Darurat Republik Indonesia
}

\author{
Erasiah \\ Universitas Islam Negeri Imam Bonjol Padang \\ Jl. Prof. Mahmud Yunus Padang, 25153 \\ e-mail: erasiah@uinib.ac.id
}

\begin{abstract}
The Emergency Government of the Republic of Indonesia is a legitimate government that is run by car or moves from one place to another during the emergency period of the Republic of Indonesia due to the second Dutch military attack. This research is carried out through library studies whose sources are found in books, both primary and secondary sources. As the primary source is Mestika Zed's work entitled Some Where in the Jungle Emergency Government of the Republic of Indonesia: A Forgotten History Chain, West Sumatra in the History Stage 1945-1995, Indonesia in the Flow of History. While secondary sources are books and articles that talk about the Emergency Government of the Republic of Indonesia. The method used in this study is a historical research method with four steps of work, namely heuristics (collecting resources), source criticism, synthesis, and writing. While the theory used to analyze Mestika Zed's thinking about the Republic of Indonesia Emergency Government is the theory of historical explanation theory of Kuntowijoyo. Kuntowijoyo said that the historical explanation has three important things (historical explanations are hermeneutic and verstehen, historical explanations are explanations of limited elongated time in space, and historical explanations are explanations of single events).
\end{abstract}

Keywords : Thought, Mestika Zed, Government, Emergency, Republic Indonesia

\section{Abstraks}

Pemerintah Darurat Republik Indonesia adalah sebuah pemerintahan yang sah yang dijalankan secara mobil atau berpindah-pindah dari satu tempat ke tempat lain dimasa darurat Republik Indonesia akibat serangan militer Belanda kedua. Penelitian ini dilakukan melalui studi kepustakaan yang sumbernya terdapat pada buku, baik sumber primer maupun sumber sekunder. Sebagai sumber primer adalah karya Mestika Zed yang berjudul Some Where in the Jungle Pemerintah Darurat Republik Indonesia: Sebuah Mata Rantai Sejarah Yang Terlupakan, Sumatera Barat Di Panggung Sejarah 1945-1995, Indonesia Dalam Arus Sejarah. Sementara sumber sekunder adalah buku-buku dan artikel yang berbicara tentang Pemerintah Darurat Republik Indonesia. Metode yang digunakan dalam penelitian ini adalah metode penelitian sejarah dengan empat langkah kerja, yaitu heuristik (mengumpulkan sumber), kritik sumber, sintesis, dan penulisan. Sementara teori yang digunakan untuk menganalisis pemikiran Mestika Zed tentang Pemerintah Darurat Republik Indonesia adalah teori penjelasan sejarah/historical explanation theory Kuntowijoyo. Kata Kuntowijoyo penjelasan sejarah itu ada tiga hal penting (penjelasan sejarah adalah hermeneutik dan verstehen, penjelasan sejarah adalah penjelasan tentang waktu yang memanjang terbatas dalam ruang, dan penjelasan sejarah adalah penjelasan tentang peristiwa tunggal).

Kata Kunci : Pemikiran, Mestika Zed, Pemerintah, Darurat, Republik Indonesia 


\section{A. Pendahuluan}

Tanggal 19 Desember 1948 adalah masa penting dan genting dalam perjalanan sejarah Indonesia. Presiden Sukarno, Wakil Presiden M. Hatta, dan beberapa petinggi negara lainnya ditangkap Belanda sebagai akibat dari aksi militer Belanda kedua setelah Indonesia merdeka. Yogyakarta diduduki, Bukittinggi diserang, dan Lubuk Linggau pun tidak luput dari penyerangan tersebut. 1 Kondisi demikian membuat Indonesia dalam keadaan darurat dan sangat kacau, Ahmad Syafii Maarif mengatakan dapatkah orang membayangkan sebuah Republik yang sedang panik tanpa PDRI? 2 yang menuntut mesti ada kebijakan untuk membela tanah air Indonesia dari tindakan brutal aksi militer Belanda kedua. Kondisi yang sangat genting itu melahirkan Syafruddin Prawiranegara sebagai salah seorang menteri negara yang tidak sempat ditangkap oleh pasukan Belanda melalui aksi militernya. Tanpa ragu-ragu dan ditopang oleh semangat membela tanah air yang didorong oleh nilai-nilai keislaman yang mengalir dalam darahnya membuatnya mengambil inisiatif membentuk pemerintah darurat.

Pemerintahan darurat tersebut berpusat di Minangkabau (Bidar Alam, Kototinggi, dan Sumpur Kudus). Pemerintahan dijalankan dipelosokpelosok nagari dan melibatkan masyarakat secara luas, baik secara perlindungan keamanan, logistik dan

\footnotetext{
${ }^{1}$ Mestika Zed, Some Where in the Jungle Pemerintah Darurat Republik Indonesia: Sebuah Mata Rantai Sejarah Yang Terlupakan, (Jakarta: Pustaka Utama Grafiti, 1997), h. 72.

2 Ahmad Syafii Maarif, Otobiografi Ahmad Syafii Maarif: Titik-Titik Kisar di Perjalananku, (Yogyakarta: Ombak, 2006), hlm. 159. Lihat juga Ahmad Syafii Maarif, Memoar Seorang Anak Kampung, (Yogyakarta: Ombak, 2013), h. 155-156.
}

lainnya. ${ }^{3}$ Akan tetapi belakangan setelah masa itu berlalu dan muncul karya-karya sejarah yang bercerita tentang sejarah Indonesia, sayangnya berita tentang PDRI hanya sebagai pelengkap dan boleh dikatakan hilang dalam pembicaraan karya sejarah, baik karya sejarah yang ditulis oleh bangsa Indonesia sendiri maupun bangsa asing pakar sejarah. Sebut saja misalnya buku Sejarah Nasional Indonesia (SNI) jilid VI sebagai buku pedoman untuk menulis buku pelajaran sejarah untuk anak sekolah. Pada buku ini kisah tentang PDRI diceritakan sedikit saja, bahkan dalam buku Sejarah Indonesia Modern 1200-2008 yang ditulis M.C. Ricklefs tidak menyebut sama sekali tentang PDRI. Selain itu di ranah politik, pimpinan PDRI pun dalam susunan Presiden Indonesia tidak disebut/hilang, padahal dalam konteks hukum tata negara pimpinan PDRI (Mr. Sjafruddin Prawiranegara) berhak disebut sebagai Presiden Negara RI. ${ }^{4}$

Kemudian muncul karya Mestika Zed seorang sejarawan yang sangat terkenal dari Sumatera Barat yang telah mengupas tentang PDRI secara padat, mulai dari awal terbentuknya PDRI sampai akhirnya penyerahan kedaulatan kembali kepada Presiden Sukarno setelah dibebaskan dan dikembalikan ke Istana Negara Yogyakarta oleh pasukan Belanda. Untuk itu pada kesempatan ini sangat tepat kiranya membincangkan pemikiran Mestika Zed tentang Pemerintah Darurat Republik Indonesia (PDRI) sebagai sebuah peristiwa sejarah yang kurang diacuhkan dalam karya sejarah lainnya

${ }^{3}$ Ibid, h. 95-97.

4 Moch. H. Kharismulloh Hilmatiar, "Pembentukan Pemerintah Darurat Republik Indonesia Tahun 1948-1949 dalam Perspektif Fiqh Siyasah dan Hukum Tata Negara", AlMazahib e-journal uin suka ac.id, Volume 3 No. 1 Juni 2015, Diunduh Tanggal 10-01-2019. 


\section{B. Pembahasan}

\section{Biografi Singkat Mestika Zed}

Sebagai seorang intelektual yang telah menginjak usia 63 tahun saat ini sangat banyak pengalaman yang dilakoni Mestika Zed. Mampu berbicara dengan 3 (Tiga) bahasa (Indonesia, Inggris, Belanda) dan menulis dengan tiga bahasa tersebut serta membaca dalam 5 (Lima) bahasa (Indonesia, Inggris, Belanda, Jerman, Perancis). ${ }^{5}$ Mestika Zed lahir pada tanggal 19 September 1955 di Batu Hampar Payakumbuh ${ }^{6}$ dari pasangan terkasih Natur Zainuddin dengan Jawanis. Berasal dari keluarga biasa (ayah seorang petani dan ibu veteran) dengan suku Pagar Cancang. 7 Sementara isterinya bernama Wahyuni Amiruddin dari keluarga terpandang dan disebut oleh masyarakat setempat dengan urang pucuak yang berasal dari suku Jambak. Wahyuni dinikahi Mestika Zed pada tahun 1986 atas perjodohan oleh keluarga. Pada saat ini isteri Mestika Zed mengajar di SMA 12 Padang.

Lahir di wilayah bekas pusat pendidikan Islam Minangkbau dan wilayah bekas salah satu pusat perjuangan PDRI tentu menghadirkan kebanggaan sendiri bagi Mestika Zed. Walaupun zamannya sudah berlalu, tetapi patut dipertimbangkan

\footnotetext{
5 Mestika Zed, "Biodata-Curiculum Vitae Mestika Zed", Pusat Kajian Sosial-Budaya dan Ekonomi (PKSBE) Fakultas Ilmu-Ilmu Sosial Universitas Negeri Padang (UNP) 2015, Internet, diunduh Tanggal 16-12-2017.

6 Mestika Zed, dkk, Sumatera Barat di Panggung Sejarah, (Jakarta: Pustaka Sinar, 1998).

${ }^{7}$ Ummu Aiman (Kasubag Akademik Fakultas Dakwah UIN Imam Bonjol Padang/tetangga Mestika Zed di Batuhampar), Wawancara, Ruang Akademik Fakultas Dakwah UIN Imam Bonjol Padang pada hari Jum'at tanggal 02 Juni 2018.
}

pengaruhnya secara psikologis terhadap Mestika Zed. Dua sisi sejarah penting menghiasi daerah kelahirannya (sebagai bekas lembaga pendidikan surau ternama dan bekas salah satu basis PDRI), tentu memberikan pengaruh besar bagi tampilnya Mestika Zed kemudian dipanggung intelektual.

Semenjak tahun 1982 sampai sekarang Mestika Zed mendapat amanah menjadi Dosen tetap pada Fakultas Ilmu-Ilmu Sosial Universitas Negeri Padang (UNP) yang sebelumnya bernama IKIP. Mata kuliah yang diasuhnya adalah Pengantar Ilmu Sosial, Teori Sosial, dan Filsafat Ilmu Sosial. Mestika Zed juga pernah menjabat Ketua Jurusan Sejarah Universitas Andalas Padang tahun 1992-1995. Mestika Zed juga mengajar pada program Pascasarjana Institut Agama Islam Negeri (IAIN) Imam Bonjol Padang yang sekarang UIN pada Prodi Sejarah Peradaban Islam dengan mata kuliah Metodologi Sejarah, Filsafat Sejarah, dan Historiografi. Selain itu dia juga pernah mengajar di Universitas Islam Negeri (UIN) Raden Fatah Palembang pada program Doktor Peradaban Islam dengan mata kuliah Globalisasi dan Dinamika Budaya Melayu.

Selain sebagai tenaga pengajar pada beberapa perguruan tinggi, Mestika Zed juga berkecimpung dalam dunia tulis menulis. Pada dunia tulis menulis ini Mestika Zed bukan hanya berkedudukan sebagai penulis/koresponden pada beberapa jurnal ilmiah baik nasional maupun internasional, tetapi dia juga berkedudukan sebagai anggota dewan redaksi dan ketua dewan redaksi. Selama 4 tahun (tahun 1987-1991) Mestika Zed adalah anggota dewan redaksi Journal Jambatan Amsterdam. Ketua Dewan Redaksi Jurnal Forum 
IKIP Padang 1993-1995. Ketua Dewan Redaksi Jurnal Tingkap, Jurnal IlmuIlmu Sosial Fakultas Ilmu-Ilmu Sosial (FIS) Universitas Negeri Padang (UNP) 1996-sekarang. Menjadi pemakalah dalam forum seminar nasional dan internasional serta menjadi tim peneliti dalam berbagai topik ditingkat internasional. Selain itu sebagai sejarawan yang terdidik dan profesional di bidangnya, telah membawanya terlibatan ditingkat internasional dalam kegiatan intelektual, seperti menjadi External Examiner for Graduate Students (Ph.D. Thesis) University Malaya, Kuala Lumpur semenjak tahun $2008 .{ }^{8}$

Kemudian baru-baru ini disaat maraknya pembicaraan tentang bangkitnya/kembalinya PKI di Indonesia, ternyata Mestika Zed juga tidak dapat melepaskan diri dari pembicaraan tentang hal tersebut. Sebuah TV swasta telah membawanya berkomentar tentang PKI. Salah satu video TV swasta yang penulis unduh di internet dan mengundangnya sebagai pembicara dalam tema "Jas Merah: Mewaspadai Kebangkitan PKI" adalah Surau TV pada tanggal 8 Mei 2017. ${ }^{9}$ Akan tetapi sebelum Mestika Zed berbicara tentang PKI di surau TV tersebut, ternyata diakhir tahun 2016 pada bulan November Mestika Zed juga sudah berbicara tentang PKI. Pembicaraan tentang PKI tersebut disampaikannya pada acara Konferensi Internasional tentang Tragedi 1965/66 yang bertajuk "Rekonsiliasi Sejarah dengan Tragedi 1965/66" yang

8 Mestika Zed, "Biodata-Curiculum Vitae Mestika Zed", Pusat Kajian Sosial-Budaya dan Ekonomi (PKSBE) Fakultas Ilmu-Ilmu Sosial Universitas Negeri Padang (UNP) 2015, Internet, diunduh Tanggal 16-12-2017.

${ }^{9}$ You Tube Surau TV Official, "Jas Merah: Mewaspadai Kebangkitan PKI”, may 8, 2017, diunduh tanggal 10 Mei 2018. diselenggarakan oleh Universitas Goethe Frankfurt Jerman pada tanggal 10-12 November 2016 dengan topik "Komunisme dan PKI di Indonesia". Konferensi tersebut dihadiri oleh para ilmuwan, sejarawan, peneliti, para ahli, mahasiswa, seniman, penggiat HAM dan demokrasi serta korban pelanggaran HAM 65 yang datang dari berbagai negara termasuk Indonesia. ${ }^{10}$

Mestika Zed juga pernah menjadi Ketua Masyarakat Sejarawan Indonesia (MSI) Cabang Sumatera Barat tahun 1993-2001. Pada tahun 1995 bersama beberapa staf pengajar lainnya di Fakultas Ilmu Pengetahuan Sosial (FPIPS) IKIP Padang dia menggagas untuk membentuk forum yang dapat mensinergikan jurusan-jurusan yang ada di fakultas tempatnya mengabdi. Akhirnya gagasan tersebut disampaikan kepada Dekan dan pada tahun 1996 dikeluarkan SK Dekan tentang resminya forum tersebut berdiri yang bernama Pusat Kajian SosialBudaya dan Ekonomi (PKSBE). Semenjak awal pembentukan Mestika Zed direncanakan sebagai Ketua PKSBE, tetapi karena pada tahun 1996 Mestika Zed memenangkan Visiting Scholar Fulbright pada Southeast Asia Program, Cornell University Ithaca, NY, USA dia tidak jadi menjadi ketua dari lembaga yang baru dibentuk tersebut. Kemudian baru dia menjadi ketua dari lembaga tersebut belakangan sampai sekarang.

Lahirnya Mestika Zed sebagai seorang sejarawan terdidik dan penulis yang produktif tentu tidak terlepas dari proses pendidikan tinggi yang dilaluinya. Pendidikan tinggi yang dilaluinya bukan hanya di dalam negeri,

10 www. Moslemtoday.com, "(Video) Guru Besar Sejarah UNP Prof. Mestika Zed: 'Waspadai Kebangkitan PKI', diunduh tanggal 10 Mei 2018. 
tetapi juga di luar negeri. Pendidikan tinggi yang dilalui Mestika Zed pertama kalinya adalah pada Jurusan Sejarah di Institut Keguruan dan Ilmu Pendidikan (IKIP) Padang selama dua tahun, yaitu pada tahun 1975 s/d tahun 1977. Herman salah seorang teman kelas Mestika Zed di jurusan sejarah tersebut menjelaskan:

"bahwa selama dua tahun satu kelas dengan Mestika Zed pada jurusan sejarah tersebut, ketekunan Mestika Zed akan ilmu pengetahuan sangat terlihat. Dia rajin ke perpustakaan dan dalam satu malam empat sampai lima buku tuntas dibacanya, sedangkan akan tugas-tugas yang diberikan dosen, Mestika Zed selalu mendapat pujian dari dosen-dosen karena tugasnya sangat bagus di samping Mestika Zed juga adalah seorang mahasiswa yang sangat aktif bertanya dalam setiap tatap muka perkuliahan. Akan tetapi dia kurang bergaul karena selalu sibuk dengan buku. Kemudian karena Lembaga Ilmu Pengetahuan Indonesia (LIPI) pada tahun 1977 mengadakan program pencakokan dosen, Mestika Zed ikut tes dalam program tersebut dan saya juga ikut. Salah seorang penguji dari program tersebut adalah Taufik Abdullah. Nasib baik berpihak kepada Mestika Zed, sehingga Mestika Zed lulus dari lima orang peserta ketika itu, sedangkan saya tidak kata Herman". 11

Memahami dari keterangan Herman tersebut dapat dimengerti, bahwa tampilnya Mestika Zed

${ }^{11}$ Herman (Dosen SKI di Fakultas Adab dan Humaniora UIN Imam Bonjol Padang), Wawancara, Jum'at tanggal 22 Juni 2018 di Ruang Dosen Lantai II Fakultas Adab dan Humaniora. sekarang sebagai seorang intelektual yang ternama dan terkenal sudah terbangun dengan rapi semenjak dia menjadi mahasiswa di IKIP Padang. Kemudian dilanjutkannya pada jurusan sejarah Universitas Gajah Mada Yogyakarta dan selesai pada tahun 1980. Kuliah Post-Graduate Programme (MA) bidang Sejarah pada Vrije Universiteit, Amsterdam selama 2 tahun (1981-1983). Setelah itu Mestika Zed mengikuti penyetaraan S2 di Pascasarjana Universitas Indonesia (1983-1984). Selanjutnya gelar Doktor Sejarah diraihnya dengan spesialisasi sejarah sosial dan ekonomi pada Jurusan Niet-Westerse Geschiedenis (Jurusan Sejarah non-Barat) Faculteit der Sociaal-culturele Wetenschappen (Fakultas Ilmu-ilmu Sosial dan Budaya Vrije Universiteit Amsterdam tahun 1991. 12

\section{Pemikiran Mestika Zed tentang Pemerintah Darurat Republik Indonesia (PDRI)}

Pemikiran Mestika Zed tentang PDRI tersebar dalam tiga buah buku. Ketiga buku yang dimaksud adalah Some Where in the Jungle Pemerintah Darurat Republik Indonesia: Sebuah Mata Rantai Sejarah Yang Terlupakan, Sumatera Barat di Panggung Sejarah, dan Indonesia dalam Arus Sejarah. Ketiga buku tersebut yang membahas sejarah seputar PDRI secara lengkap dan merupakan karya pertama dan utama Mestika Zed tentang PDRI adalah terdapat pada buku dengan judul Some Where in the Jungle Pemerintah Darurat Republik Indonesia: Sebuah Mata Rantai Sejarah Yang Terlupakan terbit pada tahun 1997.

Sementara buku dengan judul Sumatera Barat di Panggung Sejarah

12 Mestika Zed, Kepialangan Politik dan Revolusi Palembang 1900-1950, (Jakarta: LP3ES, 2003). 
terbit pada tahun 1998 yang ditulis dengan tim, informasi seputar sejarah PDRI hanyalah salah satu bab dalam buku tersebut. Demikian juga dengan buku Indonesia dalam Arus Sejarah terbit lebih belakangan, yaitu pada tahun 2012 yang penulisnya berjumlah sekitar 100 orang. Informasi seputar PDRI termuat dalam jilid 6 dengan topik besarnya Perang dan Revolusi yang merupakan bab kesepuluh. Berhubung informasi sejarah PDRI secara lengkap yang ditulis oleh Mestika Zed terdapat dalam buku yang pertama kali terbit dan itu ditulisnya sendiri, maka yang menjadi sandaran utama penulis dalam mengkonstruksi pemikiran Mestika Zed tentang PDRI adalah buku tersebut.

Pemerintah Darurat Republik Indonesia (PDRI) dalam pandangan Mestika Zed adalah suatu episode sejarah nasional Indonesia dan bukan sejarah lokal Sumatera Barat. ${ }^{13}$ Ini tidak terlepas dari bagaimana proses munculnya PDRI sebagai akibat dari terjadinya kekosongan pemimpin negara Republik Indonesia ulah agresi militer Belanda kedua. Kondisi genting demikian, Belanda menganggap Republik Indonesia sudah tamat riwayatnya, namun suatu titik balik yang tidak diduga oleh Belanda, RI tidak mati, bahkan sebaliknya mampu memerankan dirinya sebagai par excellence pemerintahan alternatif, menggantikan kepemimpinan SukarnoHatta yang ditangkap Belanda ${ }^{14}$.Pemerintahan alternatif itu (yang lebih dikenal dengan PDRI) ternyata mampu memberi energi baru dalam melanjutkan perlawanan

\footnotetext{
${ }^{13}$ Mestika Zed, Some Where in the Jungle...., hlm. iii

${ }^{14}$ Mestika Zed, "Pemerintah Darurat Republik Indonesia Republik dalam Keadaan Darurat", dalam Taufik Abdullah dan A. B. Lapian (ed), Indonesia dalam Arus Sejarah jilid 6, (Jakarta: Ichtiar Baru Van Hoeve, 2012), hlm. 413.
}

menentang hegemoni Belanda, baik pada tataran perjuangan bersenjata di dalam negeri maupun dalam mendorong keterlibatan dunia internasional terhadap tindakan Belanda tersebut.

PDRI berperan menghimpun kembali kekuatan yang berserakan dan membangun kembali kepemimpinan baru selama delapan bulan (19 Desember 1948 s/d Juli 1949) melalui kontak-kontak kurir, radio, dan telegram. $\quad 15$ Sementara Jenderal Soedirman yang mengetahui mandat yang dikeluarkan Presiden Sukarno, Wakil Presiden Muhammad Hatta, dan beberapa menteri negara dalam rapat yang tergesa-gesa pada tanggal 19 Desember 1948 sebelum mereka ditangkap Belanda melalui surat kawat, mengakui akan kepemimpinan PDRI. Adapun bunyi mandat melalui surat kawat yang dimaksud adalah sebagai berikut:

Kami Presiden Republik Indonesia, memberitahukan bahwa pada hari Minggu tanggal 19 Desember 1948 jam 06.00 pagi, Belanda telah mulai serangannja atas Ibu Kota Djogjakarta.

Djika dalam keadaan pemerintah tidak dapat menjalankan kewajibannja lagi, kami menguasakan kepada Mr. Sjafruddin Prawiranegara, Menteri Kemakmuran Republik Indonesia untuk membentuk Pemerintah Republik Indonesia Darurat di Sumatra. ${ }^{16}$

Jogjakarta, 19 Desember 1948

\section{Presiden Wakil Presiden}

\section{Soekarno Moh. Hatta}

15 Ibid, hlm. 414.

${ }^{16}$ Ahmad Mansur Suryanegara, Api Sejarah, (Bandung: Salamadani, 2012), hlm. 267. 
Akan tetapi akibat perang yang membuat situasi dan kondisi demikian kacaunya, memungkinkan kawat pertama belum diterima oleh $\mathrm{Mr}$. Sjafruddin Prawiranegara atau ada halangan lainnya. Oleh sebab itu, Wakil Presiden Mohammad Hatta dan Menteri Luar Negeri Hadji Agoes Salim, mengirimkan kawat kedua yang ditujukan kepada Dr. Soedarsono, A. N. Palar, A. A. Maramis di New Delhi. Bunyi kawatnya adalah sebagai berikut:

Kami Presiden Republik Indonesia memberitahukan bahwa pada hari Minggu tanggal 19 Desember 1948, jam 06.00 pagi, Belanda mulai serangannja atas Ibu Kota Djogjakarta. Djika ichtiar Mr. Sjafruddin Prawiranegara membentuk Pemerintah Darurat di Sumatra tidak berhasil, kepada Saudara dikuasakan untuk membentuk Exile Government Republik Indonesia di India.

Harap dalam hal ini berhubungan dengan $M r$ S Sjafruddin Prawiranegara di Sumatra. Djika hubungan tidak mungkin, harap diambil tindakan-tindakan seperlunja. ${ }^{17}$

Jogjakarta, 19 Desember 1948

Wakil Presiden

Moh. Hatta

\section{Menteri Luar Negeri \\ H. Agoes Salim}

Demikianlah kondisi Indonesia pada tanggal 19 Desember 1948 tersebut, sehingga mandat untuk membentuk pemerintah darurat pun mesti dikeluarkan dua kali dalam rentang waktu yang tidak lama. Sementara Mr. Syafruddin Prawiranegara tidak tahu akan mandat tersebut sebagaimana juga para pembesar di Sumatra juga tidak mengetahui berita penting itu. Walaupun demikian, dengan semangat membela tanah air dan menyelamatkan bangsa dari cengkraman Belanda, $\mathrm{Mr}$. Syafruddin Prawiranegara kemudian membentuk Pemerintah Darurat Republik Indonesia dan kawan-kawan. Sebagai pemegang tanggung jawab paling tinggi dalam PDRI dipakai istilah ketua bukan presiden sebagaimana biasanya. Penggunaan istilah ketua terhadap pimpinan PDRI oleh Syafruddin Prawiranegara sebenarnya juga tidak terlepas dari ketidaktahuannya akan mandat presiden. Akan tetapi sekiranya Syafruddin Prawiranegara tahu akan mandat presiden tentulah presiden istilah yang digunakannya untuk pimpinan PDRI dikala itu.

Ini senada dengan yang diungkapkan Ajip Rosidi dalam bukunya yang mengungkapkan bahwa tiga puluh tahun kemudian dalam surat kabar Pelita dimuat wawancara dengan Sjafruddin Prawiranegara (6 Desember 1978). Sehubungan dengan pemakaian istilah ketua Sjafruddin menerangkan:

Mengapa saya tidak menamakan diri Presiden Republik Indonesia tetapi Ketua Pemerintah Darurat Republik Indonesia? yang demikian itu disebabkan karena saya belum mengetahui adanya mandat Presiden Sukarno, dan didorong oleh rasa keprihatinan dan kerendahan hati .....tetapi andai kata saya tahu tentang adanya mandat tadi, niscaya saya akan menggunakan istilah Presiden Republik Indonesia, untuk menunjukkan pangkat dan jabatan saya...dengan istilah Ketua PDRI sebenarnya saya seorang Presiden Republik Indonesia dengan segala

${ }^{17}$ Ibid, hlm. 268 


\begin{abstract}
kekuasaan yang diberikan kepadanya oleh UUD 1945 dan diperkuat oleh mandat Presiden Sukarno dan Wakil Presiden Hatta, yang pada waktu itu tidak dapat bertindak sebagai Presiden dan Wakil Presiden. ${ }^{18}$
\end{abstract}

Kemudian karena persoalan RI dan Belanda tersebut sampai ke tingkat dunia, sehingga Belanda pun harus berhadapan dengan Dewan Keamanan PBB yang berujung di meja perundingan. Setelah itu Presiden Sukarno, Wakil Presiden Muhammad Hatta dan beberapa menteri negara yang ditangkap Belanda dibebaskan serta dikembalikan ke pusat negara Yogyakarta. Sementara di pihak PDRI pun tidak alpa menyerahkan kedaulatan kembali kepada Sukarno-Hatta di Yogyakarta.

Berdasarkan paparan di atas sangat jelas terlihat bahwa PDRI adalah salah satu sejarah penting Indonesia yang telah berhasil menyelamatkan RI dari tindakan brutal Belanda. Untuk itu dalam pandangan Mestika Zed peristiwa PDRI ada latar belakang munculnya, ada pembentukannya, ada konsolidasi kekuatan yang menopang eksisnya PDRI dan ada penyerahan kedaulatan. Untuk lebih jelasnya bagaimana pemikiran Mestika Zed tentang PDRI yang termuat dalam tiga karya sejarah tersebut, dapat dijelaskan sebagai berikut.

\section{a. Latar Belakang PDRI}

Pemerintah Darurat Republik Indonesia (PDRI) adalah sebuah pemerintahan darurat yang pernah terjadi di Indonesia di awal kemerdekaan. Sebagai sebuah peristiwa sejarah, tentu sebelum peristiwa itu terjadi ada hal-hal yang

\footnotetext{
${ }^{18}$ Ajip Rosidi, Sjafruddin Lebih Takut...., hlm. 114.
}

memicu atau mendukung sebuah peristiwa itu terjadi. Suatu peristiwa terjadi tidak terlepas dari latar belakang peristiwa yang menimbulkannya. Ini disebabkan sejarah lebih menekankan aspek proses suatu peristiwa sosial untuk menemukan penyebab terjadinya dalam suatu masyarakat. ${ }^{19}$

Mempelajari dan memahami secara keseluruhan dari karya Mestika Zed tentang PDRI, sebagai latar belakang munculnya PDRI adalah agresi militer Belanda kedua. Mestika Zed menjelaskan bahwa agresi militer Belanda kedua telah membuat Presiden Sukarno, Wakil Presiden M. Hatta, dan beberapa orang menteri negara ditangkap. 20 Berita tentang penangkapan mereka tersebar keseluruh Indonesia dan dunia internasional. Mendengar berita bahwa Presiden, Wakil Presiden, dan beberapa orang menteri negara tertangkap, Syafruddin Prawiranegara sebagai salah seorang menteri negara RI yang sedang berada di Sumatera mendirikan pemerintahan darurat dalam upaya menyelamatkan negara dari kekosongan pemerintahan.

Jatuhnya ibu kota Yogyakarta dan ditangkapnya sejumlah pemimpin utama RI, perjuangan rakyat Indonesia tiba-tiba mengalami degradasi, bahkan RI nyaris memasuki tahap 'koma'. Akan tetapi spirit Islam yang membara dalam darah Syafruddin Prawiranegara sebagai keturunan priyayi yang agamais $^{21}$ dan sebagai salah seorang petinggi Masyumi serta didukung oleh kawan-kawan di Minangkabau

${ }^{19}$ Irhash A Shamad, Ilmu Sejarah: Perspektif Metodologis dan Acuan Penelitian, (Jakarta: Hayfa Press, 2003), hlm. 17.

20 Mestika Zed, dkk, Sumatera Barat di Panggung Sejarah 1945-1995, (Jakarta: LP3ES, 1998), hlm. 90.

21 Ajip Rosidi, Sjafruddin Prawiranegara Lebih Takut Kepada Allah SWT, (Jakarta: Inti Idayu Press, 1986), hlm. 1. 
menopang mereka untuk melanjutkan perjuangan walaupun pimpinan utama negara ditangkap Belanda. Akhirnya atas pertimbangan yang matang PDRI dibentuk dan Sumatera/Minangkabau dijadikan sebagai pusat pemerintahan.

\section{b. Pembentukan PDRI}

Agresi militer Belanda kedua yang terjadi pada tanggal 19 Desember 1948 telah membuat rakyat Indonesia kehilangan pemimpin yang sah, karena mereka dijebloskan ke dalam penjara oleh tentara Belanda. Berita tersebut tersebar secara cepat. Awalnya Syafruddin Prawiranegara tidak percaya dan dia mengira itu adalah salah satu siasat Belanda untuk menundukkan daerah. Akan tetapi ketika Syafruddin merasa yakin bahwa berita itu bukan bohong belaka, akhirnya bersama dengan para pemimpin yang berada di Sumatera yang terpusat di Bukittinggi Syafruddin menyampaikan untuk mendirikan pemerintahan darurat.

Rapat itu terlaksana di Gedung Tri Arga Bukittinggi. ${ }^{22}$ Akan tetapi baru beberapa menit rapat berjalan dentuman senjata roket Belanda mengejutkan mereka dan rapat seketika dihentikan. Kemudian masing-masing peserta rapat menyelamatkan diri sambil bersembunyi di tempat-tempat yang dipandang aman. Setelah kondisi membaik, peserta rapat kembali berkumpul dan yang diputuskan bahwa rapat berikutnya dalam rangka mengambil keputusan tentang pembentukan pemerintah darurat akan dilanjutkan tetapi waktunya tidak jelas. Langkah yang mesti diambil cepat adalah menyelamatkan diri dari serangan Belanda.

$$
\text { Akhirnya rapat yang }
$$
menghasilkan keputusan baru di dekat

\footnotetext{
${ }^{22}$ Mestika Zed, "Pemerintah Darurat Republik Indonesia...., hlm. 424.
}

Ngarai sianok di rumah Mr. T.M. Hasan. Syafruddin tanpa ragu-ragu mengusulkan dirinya sebagai ketua dari pemerintahan darurat yang direncanakan dan menunjuk Hasan sebagai wakilnya. ${ }^{23}$ Hasan pun setuju. Kemudian pada hari berikutnya, karena suasana tidak aman para pemimpin di Bukittinggi mengungsi ke Payakumbuh dan masyarakat pun di perintahkan mengungsi.

Berhubung pemerintahan darurat yang dibentuk di rumah Hasan tersebut belum memiliki susunan pemerintahan, maka ketika di Halaban subuh tanggal 22 Desember dibentuklah susunan Kabinet PDRI dengan rangkap jabatan masing-masing individu. ${ }^{24}$ Setelah itu baru mereka berpisah ketiga tempat dalam upaya menarik rakyat secara luas untuk terlibat dalam berbagai kegiatan pemerintahan.

Sementara wilayah yang dijadikan sebagai pusat pemerintahan PDRI adalah Kototinggi di bawah pengawasan M Rasyid bersama dengan para pemimpin Sumatera lainnya yang sebelumnya berpusat di Bukittinggi. Adapun Syafruddin bersama kawankawan pergi ke Bidar Alam dan memimpin PDRI di sana. Mereka berhasil menggait dukungan penuh dari masyarakat, baik yang di Kototinggi maupun di Bidar Alam. Mestika Zed menggambarkan bahwa inilah periode perjuangan yang melibatkan partisipasi rakyat hingga ke pelosok pedalaman paling terpencil yang belum tersentuh spektrum konflik peperangan antara Indonesia-Belanda. ${ }^{25}$

Penting diketahui bahwa walaupun sekitar tiga bulan Bidar

\footnotetext{
${ }^{23}$ Mestika Zed, Some Where in the Jungle...., hlm. 97.

${ }^{24}$ Mestika Zed, "Pemerintah Darurat Republik Indonesia....", hlm. 426.

${ }^{25}$ Mestika Zed, Some Where in the Jungle ...., hlm. 300 .
} 
Alam menjadi pusat PDRI, namun kedatangan tamu penting di kampungnya dengan rasa bangga dan suka rela masyarakat Bidar Alam menyediakan rumah mereka sebagai tempat tinggal bagi tokoh-tokoh PDRI. Sekaligus dijadikan sebagai tempat berbagai kegiatan pemerintahan darurat ketika itu. Masyarakat Bidar Alam dengan senanghati memberikan bantuan kepada tokoh-tokoh PDRI baik berupa bahan makanan maupun berupa penjagaan keamanan yang mereka pergilirkan setiap malamnya. Sementara para tokoh PDRI pun tidak pelit memberikan ilmu kepada masyarakat Bidar Alam, termasuk Syafruddin Prawiranegara selaku Ketua PDRI juga tidak jarang memberikan pengetahuan politik kepada masyarakat. Di Samping dia juga berusaha lebih mendalami lagi tentang agama Islam selama di Bidar Alam, Syafruddin Prawiranegara punya kesan tersendiri terhadap sikap setiap orang tua yang dapat memberikan pengetahuan agama pada dirinya.

Akan tetapi pertahanan

Syafruddin Prawiranegara dan kawankawan di Bidar Alam yang berjalan sekitar tiga bulan itu akhirnya pun harus berakhir karena pelacakan Belanda sudah sampai ke wilayah yang amat jauh dari keramaian itu. Melalui perundingan dan pertimbangan yang matang Syafruddin Prawiranegara dan kawan-kawan akhirnya memutuskan untuk pindah ke Sumpur Kudus. Dengan demikian maka pusat PDRI beralih ke Sumpur Kudus Sementara itu karena jarak antara wilayah demikian jauhnya, maka hubungan antara Syafruddin Prawiranegara dengan kawan-kawan yang di Kototinggi terjalin melalui radio

\section{c. Konsolidasi Kekuatan PDRI}

Keberhasilan Syafruddin Prawiranegara dan kawan-kawan dalam upaya menyelamatkan Republik Indonesia dengan sistem Pemerintah Darurat Republik Indonesia (PDRI), tentunya tidak terlepas dari konsolidasi semua kekuatan yang ada ketika itu. Mustahil sebuah pemerintahan dapat dipertahankan dan menjadi pengayom rakyatnya jika kekuatan-kekuatan yang sudah ada tidak dikonsolidasikan, apalagi serangan mendadak Belanda tersebut telah membuat rakyat Indonesia terpencar-terpencar. Terlebih negara dalam kondisi genting. Tentulah negara yang sedang genting akan mudah dipatahkan oleh musuh apabila kekuatan-kekuatan yang sebenarnya dapat menyelamatkan kegentingan tersebut tidak dikonsolidasikan kekuatannya baik secara diplomasi maupun fisik.

Konsolidasi secara umum pengertiannya adalah tindakan yang dilakukan untuk memperkuat, menyatukan, dan memperteguh hubungan, persatuan, kelompok, dan sebagainya. ${ }^{26}$ Berdasarkan pengertian tersebut dapatlah dipahami bahwa konsolidasi intinya adalah menjadikan satu dari beragam jenis atau kelompok yang ada dalam sebuah perjuangan. Akan sulit mencapai sebuah tujuan dalam perjuangan tanpa konsolidasi/menyatukan kekuatan, baik secara diplomasi maupun secara fisik. Betapa pun kuat dan hebatnya kekuatan yang dimiliki oleh suatu kelompok atau golongan, tetapi ketika kekuatankekuatan yang ada tidak dikonsolidasikan/disatukan, maka kekuatan tersebut tidak akan ada artinya.

Malahan terkadang kekuatankekuatan tersebut juga sering menjadi

\footnotetext{
26 Kamus Besar Bahasa Indonesia Online, https://kbbi.web.id>konsolidasi, diunduh tanggal 16 Agustus 2018
} 
batu sandungan dalam sebuah perjuangan. Apalagi masing-masing kekuatan tersebut mementingkan diri sendiri, atau kelompok sendiri, seperti pengalaman sejarah bangsa Indonesia sebelumnya beberapa tahun lamanya. Begitu banyak kekuatan yang dimiliki oleh bangsa Indonesia dapat bebas dari penjajahan Belanda, tetapi sebagian kecil dari bangsa Indonesia sendiri lebih senang hidup sebagai abdi Belanda, sehingga Belanda berhasil menerapkan politik belah bambunya terhadap bangsa Indonesia. ${ }^{27}$

Selain itu begitu banyak peristiwa perlawanan yang dilakukan oleh bangsa Indonesia pada abad ke-19 $M$ untuk bebas dari cengkraman kolonial Belanda, tetapi karena perlawanan itu bersifat kedaerahan, sehingga perlawanan itu akhirnya pun dapat dipadamkan. Sebut saja misalnya Perang Padri, Perang Diponegoro, Perang Banten, Perlawanan Patimura di Maluku, dan lain-lain. Kenapa Belanda mudah menundukkannya karena konsolidasi kekuatan secara menyeluruh baik secara diplomasi maupun fisik belum tercipta ketika itu. Akan tetapi pada awal abad ke-20 M muncul kesadaran bangsa Indonesia untuk mengkonsolidasikan atau menyatukan semua kekuatan bangsa Indonesia melalui sumpah pemuda pada tanggal 28 Oktober 1928, perjuangan yang dilakukan pun membuahkan hasil dengan kemerdekaan Indonesia pada tanggal 17 Agustus 1945.

Beranjak dari hal tersebut, maka tentunya karena kondisi yang dihadapi oleh bangsa Indonesia di masa PDRI tidak jauh berbeda dengan masa sebelumnya apalagi bangsa yang

27 Lihat Ahmad Syafii Maarif, Islam dan Politik Teori Belah Bambu Masa Demokrasi Terpimpin (1959-1965), (Jakarta: Gema Insani Press, 1996). hendak menghidupkan kembali jiwa kolonialnya di Indonesia juga bangsa Belanda yang telah bertahun-tahun sebelumnya menjadi penguasa atas bangsa Indonesia. Untuk itu tentu dalam membendung dan menghadapi kondisi tersebut harus ada konsolidasi kekuatan yang dilakukan oleh bangsa Indonesia di zaman PDRI tersebut.

Membaca dan memahami apa yang dijelaskan oleh Mestika Zed dalam bukunya tentang PDRI, maka konsolidasi kekuatan PDRI dalam pandangan Mestika Zed menurut hemat penulis dapat dibedakan kepada tiga. Ketiga konsolidasi kekuatan yang dimaksud yaitu konsolidasi diplomasi, konsolidasi fisik, dan konsolidasi pelajar. Untuk lebih terangnya bagaimana pandangan Mestika Zed terhadap ketiga konsolidasi kekuatan tersebut dapat dilihat dalam penjelasan berikut.

\section{d. Konsolidasi Diplomasi}

Sejarah PDRI yang dipaparkan Mestika Zed dalam karyanya menurut penulis pada tahap awal mengandung unsur konsolidasi diplomasi atau penyatuan kekuatan melalui perundingan tanpa peperangan. Adapun wujud konsolidasi yang dimaksud pertama adalah bahwa pada saat Indonesia benar-benar dibombardir oleh pasukan Belanda dari darat dan udara, Syafruddin sebagai salah seorang petinggi negara menyatukan kekuatan dengan para petinggi Sumatera melalui rapat untuk membentuk pemerintah darurat yang bertempat di Gedung Tri Arga (Istana Wakil Presiden) Bukittinggi. Hal yang sama juga terjadi di ibu $\operatorname{kota}^{28}$ dan apa yang dipikirkan oleh para pemimpin di

\footnotetext{
${ }^{28}$ Mestika Zed, Some Where in the Jungle ...., hlm. 95.
} 
sini dan di pusat sana sudah sangat sejalan satu sama lain. ${ }^{29}$

Kebijaksanaan yang diambil Syafruddin dan kawan-kawan tersebut menjadi penentu terselamatkannya RI dari niat buruk Belanda ingin menjajah Indonesia kembali. Sementara kebijaksanaan yang diambil oleh Presiden, Wakil Presiden, dan beberapa petinggi di Yogyakarta memandatkan negara kepada Syafruddin belakangan menjadi penopang konsolidasi antara Syafruddin mendapat pengakuan dari TNI. Sudah dipahami bersama bahwa TNI adalah alat negara yang selalu mesti siap menjaga dan melindungi negara dari ancaman musuh. Untuk itu Jend. Soedirman sebagai komando pimpinan tertinggi TNI ketika itu yang mengetahui akan mandat Presiden dan Wakil Presiden kepada Syafruddin menyatakan berjuang bersama Syafruddin Prawiranegara dalam menyelamatkan RI.

Tidak aneh kiranya jika ketika Sukarno yang masih dalam tahanan Belanda bersedia berdiplomasi dengan Belanda amat tidak disetujui oleh Jend. Soedirman, padahal pimpinan negara yang sah ketika itu adalah Syafruddin Prawiranegara Ketua PDRI. Untuk itu ketika akhirnya persoalan Indonesia dengan Belanda harus diselesaikan di meja sidang yang diwakili oleh Muhammad Roem amat ditentang oleh Jend. Soedirman, sehingga ketika Sukarno sudah dikembalikan ke Yogyakarta oleh Belanda dari kurungan, Jend. Soedirman tidak bersedia kembali ke Yogyakarta kecuali setelah Syafruddin Prawiranegara sudah kembali ke Yogyakarta. Sikap Jend. Soedirman menunjukkan begitu besar pengakuannya akan Ketua PDRI dan tokoh-tokohnya sebagai akibat dari

\footnotetext{
${ }^{29}$ Mestika Zed, "Pemerintah Darurat Republik Indonesia...., hlm.425.
}

mandat yang dikeluarkan oleh Presiden dan Wakil Presiden.

Kedua kabinet PDRI terbentuk pada tanggal 22 Desember 1948 di Halaban dan setelah itu anggota kabinet berpisah ketiga tempat. Perpisahan ketiga tempat itu bagi Mestika Zed adalah upaya penyatuan rakyat Indonesia yang mesti diwujudkan dalam menghadang niat buruk Belanda. Syafruddin dan kawankawan menuju Bidar Alam dan mendapat dukungan dari masyarakat setempat. Dengan rasa bangga dan sukarela mereka menyediakan rumah mereka sebagai tempat tinggal bagi para tokoh PDRI, sekaligus sebagai tempat berbagai kegiatan pemerintah darurat itu. ${ }^{30}$

Mr. St. Moh. Rasyid bersama petinggi Sumatera lainnya ke Kototinggi menyusun kekuatan. Sebelum meneruskan perjalanannya, Rasyid mengadakan rapat dengan Wedana Suliki Arisun St. Alamsyah dan Camat Alimin tentang Kototinggi sebagai pusat PDRI. ${ }^{31}$ Sampai di Kototinggi karena kehadiran mereka ditunggu sejak pagi oleh masyarakat, Rasyid membuka pidatonya dalam bahasa Minang: "...kini ko kito bajuang lai, supayo masyarakaek Kototinggi ikuik pulo bajuang malawan Balando..." ("sekarang saatnya kita mulai berjuang, supaya masyarakat Kototinggi ikut pula melawan Belanda"). ${ }^{32}$

Sementara Kolonel Hidayat bersama ajudannya Islam Salim, dan lain-lain bergerak ke Utara, long march lintas Sumatera kemudian sampai di Aceh. ${ }^{33}$ Setibanya di Aceh Kol.

\footnotetext{
${ }^{30}$ Mestika Zed, Some Where in the Jungle ...., hlm. 126.

${ }^{31}$ Ibid, hlm. 133.

${ }^{32}$ Ibid, hlm. 135.

${ }^{33}$ Mestika Zed, dkk, Sumatera Barat...., hlm. 94.
} 
Hidayat menjalin hubungan dengan pemimpin paling terkemuka di Aceh, yaitu dengan Daud Beureueh dan sejumlah perwira militer yang beroperasi di Kotaraja (kini banda Aceh). Lebih penting lagi dukungan yang diberikan oleh masyarakat Aceh dimotori oleh kelompok organisasi para ulamanya PUSA (Persatuan Ulama Seluruh Aceh) ${ }^{34}$. Dia berhasil menjaring hubungan yang digambarkan oleh Mestika Zed seperti jaringan labalaba. ${ }^{35}$ Tiga sumbu pertahanan Sumatera terhubungkan dari Utara ke Selatan. Pada sumbu pertama di Utara pusatnya adalah Aceh membentang daerah target Medan, Pematang Siantar terus ke Sibolga. Sumbu kedua di tengah, yaitu dengan pusatnya Bidar Alam dan Kototinggi berhadapan dengan Padang, Bukittinggi, Payakumbuh, dan Pekanbaru Riau. Sumbu ketiga di Selatan berpusat di Lebongtandai dan Muara Aman berhadapan dengan Palembang, Lubuk Linggau, dan terus ke Bengkulu dan Lampung.

Ketiga, konsolidasi diplomasi yang terjadi masa PDRI dalam pandangan Mestika Zed sangat ditentukan oleh alat komunikasi ketika itu, tentunya adalah stasiun radio. Mestika Zed menjelaskan bahwa usaha membangun kembali hubungan antara pemimpin di Jawa dan Sumatera telah dilakukan sejak tanggal 19 Desember 1948. ${ }^{36}$ Akan tetapi karena alat yang menghubungkan Jawa dengan Sumatera telah diputus Belanda terlebih dahulu, sehingga baru satu bulan setelah berdirinya PDRI hubungan dengan Jawa terjalin. Sementara untuk menginformasikan

\footnotetext{
${ }^{34}$ Ibid, hlm. 170.

${ }^{35}$ Mestika Zed, Some Where in the Jungle ...., hlm. 172.

${ }^{36}$ Mestika Zed, Some Where in the Jungle ...., hlm. 172.
}

bahwa Indonesia masih berdiri kokoh ketika itu kepada masyarakat Indonesia secara khusus dan ke dunia internasional secara umum, satu hari setelah kabinet PDRI terbentuk Syafruddin sudah mengumumkan susunan Kabinet PDRI melalui semua stasiun radio. ${ }^{37}$

Konsolidasi diplomasi melalui stasiun radio ini hemat penulis dalam pandangan Mestika Zed sangat membantu pemecahan persoalan di masa PDRI, karena berita kebrutalan Belanda di Indonesia tersiar dengan cepat di dunia internasional dan meraih dukungan dari dunia internasional secara umum dan terkhusus dukungan dari India. Mestika Zed menjelaskan bahwa "negara pertama dan barangkali paling total dukungannya terhadap Indonesia adalah India, kemudian menjadi pusat gravitasi bagi perjuangan diplomatik RI di luar negeri. ${ }^{38}$

Begitu pentingnya stasiun radio di masa PDRI dalam pandangan Mestika Zed, sehingga ketika para pemimpin PDRI di Kototinggi mendengar Belanda sudah mengetahui pusat PDRI di sana, untuk itu generator Radio Kototinggi yang seberat dua setengah sampai tiga ton itu ditarik sekitar 15 orang untuk menyembunyikannya. Akan tetapi tempat menyembunyikannya itu kemudian dianggap tidak aman, sehingga generator itu terus ditarik menyeberangi sebuah jembatan. Cuaca sangat buruk ketika itu, karena hujan jalan jadi licin, akibatnya generator radio tersebut jatuh ke sungai dan untuk menyelamatkan agar tidak terbawa arus air sungai M. Yakub Lubis mengikatkan tali generator itu ke tubuhnya. Sampai hari gelap dia tetap

\footnotetext{
${ }^{37}$ Ibid, hlm. 190.

${ }^{38}$ Mestika Zed, "Pemerintah Darurat Republik Indonesia....", hlm. 435
} 
berdiri di sana sambil memegang tali pengikat generator tersebut. ${ }^{39}$

Keempat, konsolidasi diplomasi masa PDRI dalam percaturan dunia internasional bagi Mestika Zed, walaupun wakil Indonesia di India tidak menyebut sebagai wakil PDRI, tetapi hubungan yang dilakukan oleh perwakilan Indonesia di India dengan Indonesia tidak lain adalah dengan PDRI di Sumatera. ${ }^{40}$ Untuk itu menurut Mestika Zed resolusi yang berisikan protes rakyat Asia terhadap tindakan agresi Militer Belanda yang dibincangkan dalam Konferensi New Delhi dan Dewan Keamanan di Paris, resolusi itu juga dijiwai oleh pesanpesan Ketua PDRI dari Sumatera kepada perwakilan Indonesia. ${ }^{41}$

Sudah dijelaskan sebelumnya bahwa agresi militer Belanda kedua terhadap Indonesia sangat menyita perhatian dunia internasional. Ini terjadi karena kolonialisme yang hendak dihidupkan kembali oleh Belanda terhadap Indonesia segera tercium oleh dunia internasional dengan beragam tindakan brutal dan kebohongan mereka tentang tindakannya terhadap Indonesia dan para tokoh Indonesia yang mereka tawan. Untuk itu dalam setiap persidangan terutama di Dewan Keamanan PBB perwakilan Belanda selalu didesak untuk menyelesaikan secepatkan mungkin persoalan dengan Indonesia. Desakan-desakan dunia internasional itu adalah sebagai akibat dari tersiarnya bahwa PDRI telah berdiri di Indonesia dalam upaya menyelamatkan RI.

Kelima, dimasa akhir era PDRI konsolidasi diplomasi yang terjadi

\footnotetext{
${ }^{39}$ Mestika Zed, Some Where in the Jungle ....,, hlm. 153.

${ }^{40}$ Ibid, hlm. 222.

${ }^{41}$ Mestika Zed, "Pemerintah Darurat Republik Indonesia...., hlm. 436.
}

dalam pandangan Mestika Zed adalah terjadinya pertemuan akbar di antara petinggi-petinggi PDRI di Sumpur Kudus. Para petinggi PDRI semenjak berpisah di Halaban dan sebelumnya hanya dihubungkan oleh radio akhirnya mengadakan musyawarah besar di Sumpur Kudus dalam upaya mengambil sikap atas perjanjian RoemRoyen. Perjanjian Roem-Royen ini adalah perjanjian antara Indonesia dengan Belanda sebagai wakil Indonesia adalah M. Roem dan perwakilan Belanda adalah Van Royen. Untuk itu perjanjian tersebut disebut dengan perjanjian Roem-Royen. Perjanjian ini dalam pandangan sebagian pejuang dan petinggi Indonesia ketika itu terkesan mengesampingkan PDRI dalam perjuangan melawan keganasan Belanda pada agresi militernya yang kedua tersebut. Padahal Syafruddin Prawiranegara belum menyerahkan mandat kepada Sukarno, tetapi kenapa Sukarno sudah mengutus M. Roem untuk perwakilan Indonesia, di sinilah anehnya.

Syafruddin Prawiranegara awalnya juga tidak setuju dengan sikap Sukarno tersebut sama dengan para tokoh Indonesia lainnya, seperti Sjahril, Jend. Soedirman, dan tokoh-tokoh PDRI lainnya. Akan tetapi melalui pertimbangan yang matang, akhirnya Syafruddin Prawiranegara pun setuju dengan perjanjian Roem-Royen. Dia sadar betul karena menurutnya dia mendirikan PDRI tujuan yang tulus ikhlas $^{42}$ untuk menyelamatkan negara dari kekacauan dan kehancuran. Jika sekiranya dia bersikeras dengan pendapatnya sama dengan para tokoh lainnya, maka tidak dapat dielakkan lagi perpecahan dalam tubuh Indonesia pun akan terbuka lebar dan itu semakin

\footnotetext{
${ }^{42}$ Mestika Zed, Some Where in the Jungle ...., hlm. 288 .
} 
membuat Belanda mudah dalam menguasai Indonesia kembali.

\section{e. Konsolidasi Fisik}

Situasi genting dan mencekam menghujani tanah air Indonesia karena agresi Militer Belanda kedua membuat nadi Indonesia hampir berhenti berdenyut ketika itu. Untuk itu dengan gagah berani Kol T. B. Simatupang (Wk. Kepala Staf APRI 1948) meneriakkan:

“...Yogya telah jatuh. Presiden, Wakil Presiden dan pemimpinpemimpin kita yang lain telah tertawan. Akan tetapi apakah Republik kita telah mati? Ada seorang penulis, kalau saya tidak salah Machiavelli, yang pernah kurang lebih berkata, bahwa benteng terakhir dari negara ada dalam hati sanubari prajurit-prajuritnya. Apakah Republik kita ini mati atau hidup sekarang memang terutama tergantung pada pertanyaan apakah dia masih hidup atau tidak dalam hati perwira-perwira, bintara-bintara dan prajurit-prajurit TNI..."43

Kutipan ungkapan Kol T. B. Simatupang tersebut adalah pembuka bagi Mestika Zed dalam menjelaskan konsolidasi PDRI dan tanggapan dari Jawa. Kutipan Mestika Zed itu menjelaskan kepada pembaca bahwa walaupun perang terbuka bersenjata antara pasukan PDRI dengan Belanda tidak terlihat, itu karena pusat pemerintahan PDRI tidak terletak di perkotaan sebagaimana mestinya, melainkan terletak dipelosok nagari dan itu tidak satu tempat tetapi berada pada dua tempat awalnya, yaitu Kototinggi dan Bidar Alam.

\footnotetext{
${ }^{43}$ Ibid, hlm. 189.
}

Belakangan Bidar Alam ditinggalkan karena situasi sudah mulai tidak aman dari intaian Belanda dan akhirnya pindah ke Sumpur Kudus.

Walaupun demikian adanya bentuk pemerintahan masa PDRI, tetapi sebagai alat pengawal dan pengamanan negara konsolidasi fisik ini tetap ada dalam pandangan Mestika Zed. Adapun bentuk konsolidasi fisik yang dimaksud adalah pertama, Bidar Alam sebagai tempat Syafruddin Prawiranegara Ketua PDRI berkedudukan, konsolidasi fisik yang dijelaskan oleh Mestika Zed adalah tentang penjagaan keamanan wilayah tersebut dari Belanda. Wali Perang $\mathrm{H}$. Ali Dt. Rajo Alam diperintahkan untuk menerapkan wajib ronda malam secara bergiliran bagi setiap pemuda. $\quad 44$ Kegiatan ronda berada di bawah pengawasan tentara.

Badan Pengawal Nagari dan Kota (BPNK) yang pernah dibentuk beberapa bulan sebelumnya diaktifkan kembali. Semuanya langsung di bawah pengawasan Idris Batangtaris, salah seorang perwira militer yang ikut rombongan PDRI dari Bukittinggi. Selain itu ada lagi satuan pasukan khusus "pemburu", tugas mereka adalah mengawasi dan memeriksa ladang-ladang dan semak-semak. ${ }^{45}$ Semua ini dilakukan adalah dalam upaya menjaga dan mengawasi terus kalau-kalau nanti ada pasukan Belanda atau mata-mata Belanda yang mengintai wilayah Bidar Alam.

Kedua, bentuk konsolidasi fisik dalam pandangan Mestika Zed ketika mengupas tentang PDRI di Kototinggi bahwa suasana menghadapi perang diperlukan kepemimpinan yang dinamis dan berdisiplin tinggi dengan fokus tugas masalah keamanan dan pertahanan. Lebih-lebih markas

\footnotetext{
${ }^{44}$ Ibid, hlm. 126.

${ }^{45}$ Ibid, hlm. 127.
} 
Belanda ada di Payakumbuh yang sangat dekat dengan salah satu pusat PDRI yaitu di pedalaman (Kototinggi). Untuk itu akhirnya terjadi proses militerisasi sipil. Adapun wujud dari proses militerisasi sipil ini muncullah istilah yang sebelumnya tidak digunakan. Ada gubernur militer, bupati militer, camat militer, kecuali untuk wali nagari disebut dengan Wali Perang. ${ }^{46}$

Dijelaskannya bahwa yang mula-mula dihidupkan oleh Residen Rasyid ialah Dewan Pertahanan Daerah (DPD). ${ }^{47}$ Rasyid segera menarik kembali hampir semua anggotanya, Dr. Ali Akbar, Orang Kayo Ganto Suaro, Abdullah, Bachtaruddin, Duski Samad, Tengku Radja Baharoeddin, yang diperkuat oleh sejumlah perwira militer seperti Letkol Dahlan Ibrahim dan sejumlah staf intelijennya serta wakilwakil organisasi masyarakat. ${ }^{48}$

Tokoh sipil yang paling terkemuka berdampingan dengan Rasyid adalah Chatib Soelaeman. Dia adalah orang pertama dalam MPRD (Markas Pertahanan Rakyat Daerah) yang merekrut pemuda ke dalam Giyugun dan dikenal juga sebagai tokoh perintis dalam pembentukan BPNK (Badan Pengawal Nagari dan Kota). ${ }^{49}$ BPNK ini merupakan tulang punggung yang efektif dalam menjaga keamanan nagari. Sementara untuk penjagaan di tingkat kecamatan dipegang oleh PMT (Pasukan Mobil Teras). Sementara untuk pengawasan di Bukittinggi khususnya Kamang di bawah pimpinan Kol. Dahlam Djambek. Selain itu berbagai macam

\footnotetext{
${ }^{46}$ Mestika Zed, dkk, Sumatera Barat....,hlm. 99.

${ }^{47}$ Mestika Zed, Some Where in the Jungle ...., hlm. 136.

${ }^{48}$ Ibid.

${ }^{49}$ Hikmat Israr, Chatib Sulaiman, (Bandung: Budaya Media, 2019), hlm. 137.
}

nama organisasi kurir dan intelijen sipil dibentuk. ${ }^{50}$

Ketiga, bentuk konsolidasi kekuatan fisik yang lainnya adalah ketika penyerangan balik ke ibu kota Yogyakarta pada tanggal 1 Maret 1949 yang digagas oleh Sri Sultan Hamengku Buwono IX. Semenjak ditangkapnya Presiden Sukarno, Wakil Presiden M. Hatta, dan beberapa menteri negara di Istana Yogyakarta, Sri Sultan Hamengku Buwono IX melihat semangat masyarakat Indonesia ketika itu hampir pudar untuk melakukan perlawanan terhadap Belanda, karena masyarakat telah menyaksikan sendiri bagaimana pemimpin negara menyerah begitu saja atas tindakan Belanda. Di samping itu dalam situasi yang amat genting itu, Sri Sultan Hamneku Buwono IX tidak alpa mendengarkan berita di radio tentang tanggapan dunia internasional terhadap tindakan brutal Belanda atas Indonesia.

Situasi demikian melahirkan ide bagi Sultan untuk melakukan penyerangan balik terhadap ibu kota negara Indonesia yang dijaga sangat ketat oleh Belanda. Ide tersebut disampaikan Sultan kepada Jenderal Soedirman melalui surat dan Jenderal Soedirman pun bersetuju atas ide Sultan tersebut dengan saran agar Sultan menghubungi Resimen Yogya. Saran tersebut didengar dan dilaksanakan Sultan dengan menghubungi Soeharto yang merupakan Resimen Yogya ketika itu. Melalui perencanaan dan penyusunan siasat yang dilakukan oleh Soeharto bersama pasukannya, akhirnya penyerangan balik tersebut membuahkan hasil dengan didudukinya Yogyakarta selama 6 jam dan semangat masyarakat untuk melawan tindakan Belanda pun dapat dipulihkan kembali.

\footnotetext{
${ }^{50}$ Mestika Zed, dkk, Sumatera Barat....,hlm. 99.
} 
Ide dan penyerangan balik ini dalam pandangan Mestika Zed adalah salah satu bagian dari konsolidasi kekuatan fisik PDRI. Untuk menguatkan jika penyerangan balik tersebut merupakan bagian dari konsolidasi kekuatan fisik PDRI, Mestika Zed menjelaskan bahwa stasiun radio/telegrafis PHB yang dipimpin oleh Raden Sumadi yang diperbantukan kepada gubernur militer menyiarkan berita mengenai pertempuran dan mengirimkan laporan kepada Panglima Besar Soedirman di Sobo dan Ketua PDRI di Sumatera. ${ }^{51}$ Jadi walaupun PDRI berpusat di Minangkabau dan penyerangan balik tersebut hanya dilakukan oleh pasukan yang ada di Yogyakarta, tetapi hasil dari penyerangan balik tersebut tetap dilaporkan kepada Ketua PDRI sebagai bukti pengakuan tunduk mereka atas PDRI.

\section{f. Konsolidasi Pelajar}

Menganalisis isi informasi yang terdapat dalam karya Mestika Zed tentang PDRI, hemat penulis konsolidasi pelajar juga menjadi hal yang penting dalam pandangan Mestika Zed sebagai salah satu bagian dari konsolidasi kekuatan PDRI. Ini dapat dilihat pada penjelasan Mestika Zed bahwa untuk membantu menyukseskan konferensi yang akan diadakan di New Delhi India organisasi pelajar Indonesia (PPI) di India di bawah pimpinan W.E. Sumanti (ketua), J.T. Dedeng (penulis), dan J.E.P Ontoh (bendahara) mengorganisasi suatu aksi unjuk rasa secara besar-besaran. ${ }^{52}$

Tujuan aksi demonstrasi itu ialah menarik perhatian dunia dengan cara melakukan aksi boikot terhadap kapal-kapal Belanda yang

\footnotetext{
${ }^{51}$ Mestika Zed, Some Where in the Jungle ..., hlm. 208

52 Ibid, hlm. 220.
}

menggunakan jasa pelabuhan udara dan laut India. Ternyata upaya dari para pelajar Indonesia di India tersebut mendapat respon dengan baik dari berbagai kalangan. Mereka berhasil melibatkan sekitar 700 buruh pelabuhan, di antaranya termasuk pekerja Indonesia yang bekerja di pelabuhan atau di kapal Belanda yang berlabuh di Bombay, mereka mulamula mogok di atas kapal-kapal Belanda dan kemudian turun ke darat melakukan aksi protes. ${ }^{53}$

Hal yang sama diikuti oleh Pakistan dan Ceylon (sekarang Sri Langka). Tanggal 22 Desember pemerintah Ceylon mengumumkan bahwa semua fasilitas pelabuhan laut dan udara di negerinya tertutup untuk kapal-kapal dan pesawat terbang Belanda. ${ }^{54}$ Organisasi serikat pekerja Pakistan dan India segera mengeluarkan pernyataan serupa dan mahasiswa-mahasiswa Burma di Rangoon bersama-sama dengan mahasiswa India dan Indonesia di Bombay juga melakukan aksi protes, sedangkan di Karachi kemarahan rakyat Pakistan dinyatakan dengan aksi unjuk rasa ke Kedutaan Belanda di kota itu. ${ }^{55}$

Akibat dari konsolidasi pelajar tersebut membuat Belanda secara tibatiba kehilangan pangkalan pelabuhan tempat singgah mereka dalam perjalanan dari Eropa ke Asia, khususnya ke Indonesia dan sebaliknya. Kelancaran lalu lintas kapal Belanda yang mengangkut tentara dan bahan-bahan amunisinya ke Indonesia menjadi kacau. Bagaimana tidak akan kacau, karena satu-satunya jalur laut yang menghubungkan Eropa dengan Indonesia selama ribuan tahun adalah India., Ceylon (Sri Langka) dan

\footnotetext{
${ }^{53}$ Ibid

${ }^{54}$ Ibid

${ }^{55}$ Ibid
} 
Pakistan. Sekarang fasilitas itu tertutup untuk Belanda. Bukankah untuk mengangkut tentara dalam jumlah yang banyak mau tidak mau menggunakan kapal.

\section{g. Penyerahan Mandat Kembali}

Pertikaian Indonesia-Belanda di masa PDRI telah melibatkan masyarakat secara luas sampai ke dunia internasional. Untuk itu agar konflik Indonesia-Belanda berakhir, perwakilan Belanda di PBB didesak untuk secepat mungkin menyelesaikan konflik tersebut. Menanggapi tuntutan dari Dewan Keamanan PBB dan sulitnya Belanda menghadapi Indonesia di masa PDRI, membuat Belanda mengambil sikap dengan mengadakan perundingan antara Indonesia dengan Belanda yang belakangan dikenal sebagai RoemRoyen.

Menanggapi rencana RoemRoyen tersebut, karena Syafruddin masih sebagai pimpinan PDRI yang sah ketika itu dan mandat belum dicabut oleh Sukarno. Sementara Sukarno telah mengutus Muhammad Roem untuk berdialog dengan perwakilan Belanda Van Royen. Akibatnya pimpinan PDRI mengadakan pertemuan di Sumpur Kudus pada tanggal 14 s/d 17 Mei 1949 dan itu adalah pertemuan pertama antara pemimpin PDRI semenjak mereka berpisah di Halaban pada tanggal 22 Desember 1948. ${ }^{56}$

Pertemuan akbar itu adalah untuk merapatkan barisan tentang sikap yang akan diambil PDRI tentang perjanjian Roem-Royen. Rapat menghasilkan menolak Roem-Royen. Sementara Moh. Hatta berusaha menemui Syafruddin Prawiranegara sebelum kembali ke Yogyakarta. Moh.

\footnotetext{
${ }^{56}$ Mestika Zed, dkk, Sumatera Barat....., hlm. 100.
}

Hatta berangkat ke Aceh untuk menemui Syafruddin Prawiranegara, namun ternyata Moh. Hatta tidak berhasil menemuinya dan akhirnya menunjuk delegasi untuk menemui Syafruddin Prawiranegara dan membawanya kembali ke Yogyakarta. Delegasi yang diutus adalah Moh. Natsir sebagai ketua, dr. Leimena dan A. Halim sebagai anggota serta Agus Djamal sebagai sekretaris.

Delegasi tersebut dijanjikan oleh pihak PDRI bertemu di daerah Koto Kaciek, Talago. Akhirnya terjadilah perbincangan yang alot antara mereka pada tanggal 6 Juli 1949 sampai larut malam, tetepi tidak menghasilkan keputusan apa-apa. Subuh 7 Juli 1949 saat pergi ke pancuran untuk mandi mereka bertemu kembali dan setelah mandi antara delegasi utusan moh. Hatta dengan Syafruddin dan kawan-kawan bercanda gimana jadinya. Akhirnya Syafruddin Prawiranegara setuju untuk kembali ke Yogyakarta. Itu dilakukannya penuh pertimbangan dan tujuan awal dibentuknya PDRI menurut Syafruddin adalah untuk mempertahankan negara RI dari kehancuran serta pecah belah dengan penuh ikhlas dan rendah hati Syafruddin sebagai ketua PDRI setuju kembali ke Yogyakarta dan menyerahkan mandat kembali kepada Sukarno pada tanggal 13 Juli 1949 dalam sidang kabinet pertama di bawah pimpinan Hatta. ${ }^{57}$

\section{Kesimpulan}

Berdasarkan penjelasan di atas dapat disimpulkan bahwa pertama dalam pandangan Mestika Zed Pemerintah Darurat Republik Indonesia (PDRI) adalah salah satu episode sejarah Nasional Indonesia. Kedua kehadiran PDRI menjadi pemerintahan alternatif yang amat penting dalam

\footnotetext{
${ }^{57}$ Ibid. hlm. 103.
} 
upaya menyelamatkan negara RI dari tindakan brutal Belanda. Ketiga keberhasilan PDRI dalam menyelamatkan Negara Republik Indonesia dari kehancuran, tidak terlepas dari berbagai konsolidasi kekuatan yang ada ketika itu.

\section{Daftar Pustaka}

Hilmatiar, Moch. H. Kharismulloh, “ Pembentukan Pemerintah Darurat Republik Indonesia Tahun 19481949 Dalam Perspektif Fiqh Siyasah dan Hukum Tata Negara", AlMazahib, ejournal uin suka ac. Id, Volume 3 No.I, Juni 2015. Diunduh Tanggal 10-01-2019.

Israr, Hikmat, Chatib Sulaiman, Bandung: Budaya Media, 2019.

Kartodirdjo, Sartono, Pemikiran dan Perkembangan Historiografi Indonesia, Yogyakarta: Ombak 2014.

Kuntowijoyo, Metodologi Sejarah, Yogyakarta: PT. Tiara Wacana Yogya, 2003.

Pengantar Ilmu Sejarah, Yogyakarta: PT. Tiara Wacana, 2013.

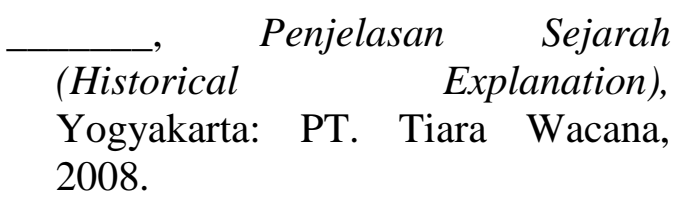

Kahin, Audrey, Dari Pemberontakan ke Integrasi: Sumatera Barat dan Politik Indonesia 1926-1998, terj. Jakarta : Yayasan Obor Indonesia, 2005.

Pergolakan Daerah Pada Awal Kemerdekaan, terj. Jakarta: Pustaka Utama Grafiti, 1989.
Kamus Besar Bahasa Indonesia Online, https://kbbi.web.id > konsolidasi, diunduh tanggal 16 Agustus 2018. Maarif, Ahmad Syafii, Otobiografi Ahmad Syafii Maarif: Titik-Titik Kisar di Perjalananku, Yogyakarta: Ombak, 2006. Kampung, Yogyakarta: Ombak, 2013.

Rosidi, $\quad$ Ajip, Sjafruddin Prawiranegara Lebih Takut Kepada Allah SWT, Jakarta: Inti Idayu Press, 1986.

Ricklefs, M.C, Sejarah Indonesia Modern 1200-2008, Jakarta: Serambi, 2008.

Shamad, Irhash A, Ilmu Sejarah: Perspektif Metodologis dan Acuan Penelitian, Jakarta: Hayfa Press, 2003.

Suryanegara, Ahmad Mansur, Api Sejarah, Bandung: Salamadani, 2012.

Syofiardi Bachyul Jb, "Pesan Mestika Zed untuk Meluruskan Sejarah", dalam Blog Minangkabau's, Diunduh Tanggal 5 Maret 2018.

www.Moslemtoday.com, "(Video) Guru Besar Sejarah UNP Prof. Mestika Zed: 'Waspadai Kebangkitan PKI', diunduh tanggal 10 Mei 2018.

You Tube Surau TV Official, "Jas Merah: Mewaspadai Kebangkitan PKI", may 8, 2017, diunduh tanggal 10 Mei 2018.

Zed, Mestika Pemerintah Darurat Republik Indonesia: Sebuah Mata 
Rantai Sejarah Yang Terlupakan, Jakarta: Pustaka Utama Grafiti, 1997.

, dkk, Sumatera Barat di Panggung Sejarah 1945-1995, Jakarta: Pustaka Sinar, 1998.

\section{Kepialangan Politik dan}

Revolusi Palembang 1900-1950, Jakarta: LP3ES, 2003.

"Pemerintah Darurat Republik Indonesia: Republik dalam Keadaan Darurat", dalam Abdullah, Taufik, dkk (ed), Indonesia Dalam Arus Sejarah Indonesia, jilid 6, Jakarta: Ichtiar Baru Van Hoeve, 2012.

"Biodata-Curiculum Vitae Mestika Zed", Pusat Kajian SosialBudaya dan Ekonomi (PKSBE) Fakultas Ilmu-Ilmu Sosial Universitas Negeri Padang (UNP) 2015, Internet, diunduh Tanggal 1612-2017.

Wawancara dengan Mestika Zed via email dan bertemu langsung, wawancara dengan Herman teman kelas Mestika Zed di IKIP Padang, wawancara dengan Ummu Aiman tetangga Mestika Zed di Batu Hampar Payakumbuh, dan wawancara dengan Mal An Abdullah teman kos Mestika Zed di Jakarta Universitas Indonesia. 